\title{
Reconstruction of Polyhalite Ore-Formed Temperature from Late Middle Pleistocene Brine Temperature Research in Kunteyi Playa, Western China
}

\author{
Jun Li $\left(\mathbb{D},{ }^{1,2,3}\right.$ Wenxia Li, ${ }^{1,2,3}$ Weiliang Miao,, ${ }^{1,2}$ Qiliang Tang, ${ }^{1,2}$ Yongshou Li, ${ }^{1,2}$ \\ Xiaolong Yuan, ${ }^{1,2}$ Qingyu Hai, ${ }^{1,2}$ Yongsheng Du, ${ }^{1,2}$ and Xiying Zhang $\mathbb{D}^{1,2}$ \\ ${ }^{1}$ Key Laboratory of Comprehensive and Highly Efficient Utilization of Salt Lake Resources, Qinghai Institute of Salt Lakes, \\ Chinese Academy of Sciences, Xining, Qinghai 810008, China \\ ${ }^{2}$ Qinghai Provincial Key Laboratory of Geology and Environment of Salt Lakes Xining, Qinghai 810008, China \\ ${ }^{3}$ University of Chinese Academy of Sciences, Beijing 100049, China
}

Correspondence should be addressed to Xiying Zhang; xyzhchina@isl.ac.cn

Received 27 May 2021; Revised 18 November 2021; Accepted 23 November 2021; Published 13 January 2022

Academic Editor: Jinze Xu

Copyright () 2022 Jun Li et al. This is an open access article distributed under the Creative Commons Attribution License, which permits unrestricted use, distribution, and reproduction in any medium, provided the original work is properly cited.

\begin{abstract}
Kunteyi Salt Lake (KSL), located in the northwest of the Qaidam Basin (QB), is rich in polyhalite resources. However, there is no relevant research on the ore-formed temperature of polyhalite in nature, such as KSL. The homogenization temperature $\left(T_{\mathrm{h}}\right)$ of salt mineral inclusions can directly reveal the form temperature of minerals. In view of the poor diagenesis of polyhalite in KSL, almost no polyhalite crystals are formed. Therefore, the ore-formed temperature of polyhalite in KSL is revealed by using the $T_{\mathrm{h}}$ of fluid inclusions in halite associated with polyhalite as a substitute index. A total of $472 T_{\mathrm{h}}$ data from 34 halite samples and 34 maximum homogenization temperature $\left(T_{\mathrm{hMAX}}\right)$ data ranged from $17.1^{\circ} \mathrm{C}$ to $35.5^{\circ} \mathrm{C}$, among which 24 data were concentrated at $17-23^{\circ} \mathrm{C}$ and the average value is $22.1^{\circ} \mathrm{C}$. Brine temperature of other salt lakes in $\mathrm{QB}$ and paleoclimate characteristics of the study area were combined. It suggests that the temperature conditions of polyhalite mineralization in the study area are generally low. However, under the overall low-temperature background, polyhalite seems to be easily enriched at relatively high temperature; for example, the content of polyhalite is generally high in the first relatively dry and hot salt-forming period, and the brine temperature at the peak stage of polyhalite at $45 \mathrm{~m}$ is relatively high, which indicates that the high temperature conditions promote the formation of polyhalite in KSL. As far as the overall relationship between temperature and polyhalite is concerned, polyhalite is deposited at both low temperature and relatively high temperature, which verifies the previous understanding that polyhalite is a mineral with wide temperature phase, and also shows that temperature has a limited effect on polyhalite formation under natural conditions. In addition, combined with the chemical composition of halite fluid inclusions, it is found that the concentration of $\mathrm{Mg}^{2+}$ in nature has an influence on the temperature measurement process. According to the previous experimental research, speculate that the actual temperature of ancient brine and ore-formed temperature of polyhalite in KSL are lower than the measured $T_{\mathrm{h}}$. The confirmation of the influence of $\mathrm{Mg}^{2+}$ on temperature measurement is convenient for more accurate reconstruction of the metallogenic temperature of evaporite such as polyhalite. The research on the ore-formed temperature of KSL polyhalite enriches and perfects the polyhalite mineralization theory and provides theoretical basis for the basic and applied research of polyhalite.
\end{abstract}

\section{Introduction}

As a hydrated $\mathrm{K}, \mathrm{Ca}$, and $\mathrm{Mg}$ sulfate mineral $\mathrm{K}_{2} \mathrm{Ca}_{2} \mathrm{Mg}(-$ $\left.\mathrm{SO}_{4}\right)_{4} \cdot 2 \mathrm{H}_{2} \mathrm{O}$, polyhalite is widely distributed in evaporite deposits, although the phase diagram study shows that the metallogenic conditions are harsh. It is a new trend in the development of international potash fertilizer industry to make potassium sulfate (SOP) from polyhalite $[1,2]$. Therefore, the 
research on polyhalite has never been interrupted. With the bottleneck of searching for potassium salt deposits in China and the depletion of potassium salt resources, polyhalite as a potassium-bearing mineral will become an important continuous potassium resource. Some typical foreign polyhalite deposits, such as Permian in England, Drawell Basin in America, and Great Kavir Basin in Iran and Spain, are mainly marine sediments and mostly metasomatic secondary minerals [3-5]. The Triassic polyhalite in the Sichuan Basin is the most typical in China. Studies have shown that it was formed by metasomatism of anhydrite from foreign $\mathrm{K}^{+}$- and $\mathrm{Mg}^{2+}$-rich solutions, and some scholars believe that it was formed by metasomatism of gypsum by seawater concentration [6-8]. Polyhalite also have been discovered in the Tertiary salt-bearing series in Lop Nur, Jianghan Basin, and Bohai Bay [9-11]. The polyhalite in the Qaidam Basin (QB) is mainly distributed in KSL in the northwest of the basin, and other salt lakes are also distributed but not large-scale. Kunteyi polyhalite was located in the prospecting stage in the early stage and has been further studied in recent years. The study shows that the polyhalite produced in the halite layer is widely distributed and low in content, while the clastic layer is narrow in distribution and high in content, and it is considered that the polyhalite in the halite layer is a primary mineral $[12,13]$. Metallogenic simulation study proves that its formation is related to Tertiary oilfield brine upwelling along the fault, and the higher the temperature, the more favorable it is for mineralization [14]. In recent years, the laboratory experimental study of polyhalite has increased, the effect of high-temperature calcination on the mineral structure of polyhalite was observed $[15,16]$, and thermodynamics and metallogenic facies area of natural polyhalite were studied [17-19]. It can be seen that the research on polyhalite has been comprehensive, but there are few reports on the ore-formed temperature of polyhalite in nature.

The polyhalite produced in the halite layer of KSL is a primary mineral, which provides the possibility to study its oreformed temperature by using the $T_{\mathrm{h}}$ of the fluid inclusions in the primary halite associated with polyhalite. Fluid inclusions in halite can provide direct, quantitative paleotemperature data. The "cooling nucleation" method of pure liquid-phase primary halite fluid inclusion [20] can accurately test the brine temperature during the crystallization of halite. The $T_{\mathrm{h}}$ of the primary single liquid-phase halite fluid inclusions distributed in cumulate and chevron halite crystal growth bands can reflect the temperature and variation characteristics of ancient brine during salt formation [21-26]. The $T_{\mathrm{h}}$ recorded by halite fluid inclusions in shallow water is similar to atmospheric temperature, which is widely used in paleoclimate research [27-32]. The reliability of the $T_{\mathrm{h}}$ index of halite fluid inclusions and the maturity of its testing technology are further explained. In this work, the temperature of KSL brine is reconstructed by studying the $T_{\mathrm{h}}$ of the primary halite fluid inclusions in the core halite salt layer; finally, the ore-formed temperature of polyhalite is revealed directly.

The ore-formed temperature of salt minerals is mostly studied directly by using fluid inclusions in the minerals. Because all the salt lakes in QB are inland Quaternary modern salt lakes, the polyhalite minerals deposited in them have poor diagenesis, are mostly soil-like cements, and have no inclusions developed, so it is impossible to directly use their inclusions to study the ore-formed temperature. Therefore, the study of ancient brine temperature indirectly indicates the characteristics of polyhalite oreformed temperature, which is rarely reported in the study of evaporite mineralization temperature. It is feasible in theory, an exploratory study, and a certain initiative. The initiation and implementation of this research method will greatly facilitate the revelation of the significance of temperature to potassium salt minerals such as carnallite and sylvinite and other evaporated salt minerals with unsatisfactory inclusions. Although this research is groundbreaking and distinctive, at the same time, there are some shortcomings. A total of 34 samples were collected in the evaporation salt layer of about $51 \mathrm{~m}$, and 472 temperature data were measured. This data is small, and the data closer to the actual situation cannot be obtained from the statistical significance to the maximum extent.

\section{Geological Setting}

KSL is a secondary faulted basin in the northwest of QB, which consists of Kunteyi Dry Salt Lake, Kunteyi Lake, and Potassium Lake (Figure 1). It is a chloride-type comprehensive deposit with dry salt lake and brine lake coexisting, mainly composed of halite and potassium salt [33]. At the end of the early Pleistocene, with the separation of Qaidam ancient lakes, the Kunteyi Basin became a secondary lake basin in QB and gradually evolved into a dry salt lake [34]. This area is located in the tectonic units-Kunlun fold system and Qilian fold system, which was formed under the strong influence of Altun Mountain strike-slip fault, showing welldeveloped fault blocks and strong folds, with many faults developed and having an important impact on the mineralization of salt lakes $[35,36]$. There is no surface recharge water body in the study area. The ice and snow melt water in the northern Altun Mountain replenishes the groundwater in front of the mountain through bedrock fissures and surface flood infiltration. The deep water discharge as seeps along the fault and the confined water at the front of the alluvial fan also account for a certain proportion of recharge [37]. In addition, the large (small) Haerten River supplies the salt lake by underground undercurrent after entering Sugan Lake, which is an important river supply source in the lake area [1]. Borehole ZK3608 is located near the mineral deposition center of Kunteyi Playa. The average sedimentation rate of Kunteyi Salt Lake since $730 \mathrm{ka}$ is $4 \mathrm{~m} / 10^{4} \mathrm{a}$ [38]. According to this deposition rate, the age of $75.25 \mathrm{~m}$ of the ZK3608 final hole is about $188 \mathrm{ka}$. ZK3208 is adjacent to ZK3608 and has the same stratigraphic sequence. Based on the chronological data of ZK3208 [39], it is calculated that the final pore age of ZK3608 is about $180 \mathrm{ka}$, which is basically consistent with the age obtained by the sedimentation rate, so it is determined to be the late Middle Pleistocene.

The study of the salt-forming period in western QB shows that the cold and dry climate since the middle and late Pleistocene has led to the concentration of lake water until it dried up, which is an important salt-forming period [41]. Through the study of minerals and elements in the core 


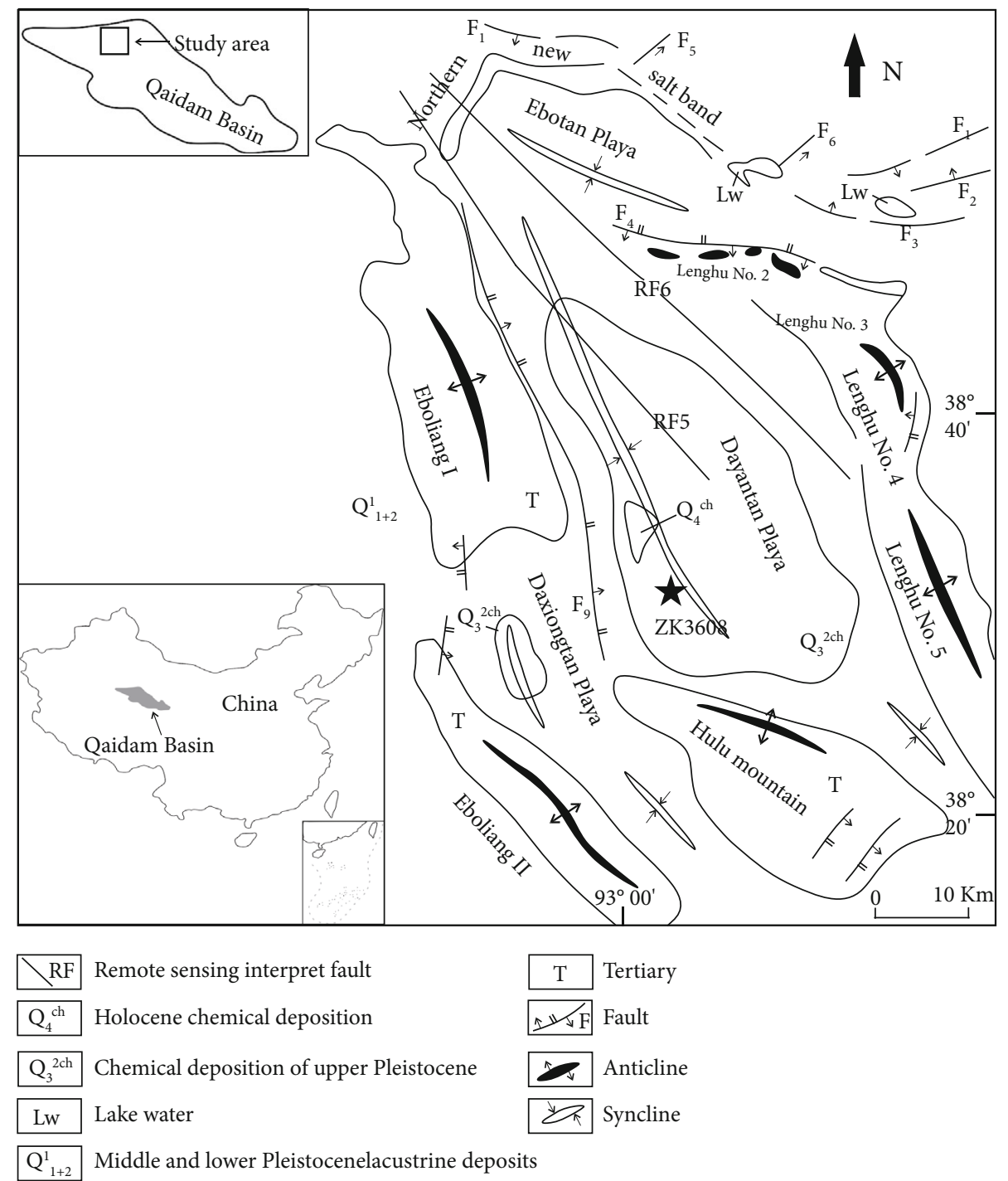

FIgURE 1: Schematic geological map of Kunteyi Playa in QB, China, and the location of core ZK3608 (modified after [40]).

section ZK3208 of Dayantan, it is found that the salt layer was formed in dry and cold acidic oxidation environment, and the salt-forming environment in the middle and late stage was mainly dry and cold [28]. The study of $\delta^{37} \mathrm{Cl}$ of rock salt shows that the climate in the study area has developed from $240 \mathrm{ka}$ to a drier and colder direction [42]. The CONISS clustering program divides the sediments from borehole 1045 in the Kunteyi Basin since the late Pleistocene into three mineral assemblage zones, all of which reflect the dry and cold climate [43]. It shows that the climate environment is mainly dry and cold in the middle and late saltforming stage of Kunteyi Salt Lake.

\section{Materials and Method}

The petrographic observation instrument of halite and fluid inclusions is a Zeiss polarizing microscope (Axioskop 40 Pol); a Linkam THMS 600 (manufactured in England) cooling and heating stage frozen using liquid nitrogen was employed for the measurement of $T_{\mathrm{h}}$. The temperature range measured by this instrument is -196 to $+600^{\circ} \mathrm{C}$, and the error is $\pm 1^{\circ} \mathrm{C}$.

3.1. Materials. Halite samples for $T_{\mathrm{h}}$ analysis were collected from the borehole ZK3608 in the Dayantan depression in the Kunteyi Playa of northwest QB (Figure 1). ZK3608 lithology has a depth of $75.25 \mathrm{~m}$ and contains 9 evaporiteclastic sedimentary cycles [13]. According to the systematic sorting and cataloging of core profiles, the halite layer is $51.1 \mathrm{~m}$ in total and primary polyhalite is widely distributed in the halite layer (Figure 2). A total of 45 halite samples were obtained by high-resolution sampling of the halite layer. Preliminary screening of lithosol particles with obvious primary characteristics, such as self-crystallization, was performed for systematic observation of petrography. Primary halite refers to the halite evaporated from lake water, and the crystals are mostly cumulate crystals and chevron crystals [44-46]. Cumulate crystals and chevron crystals 


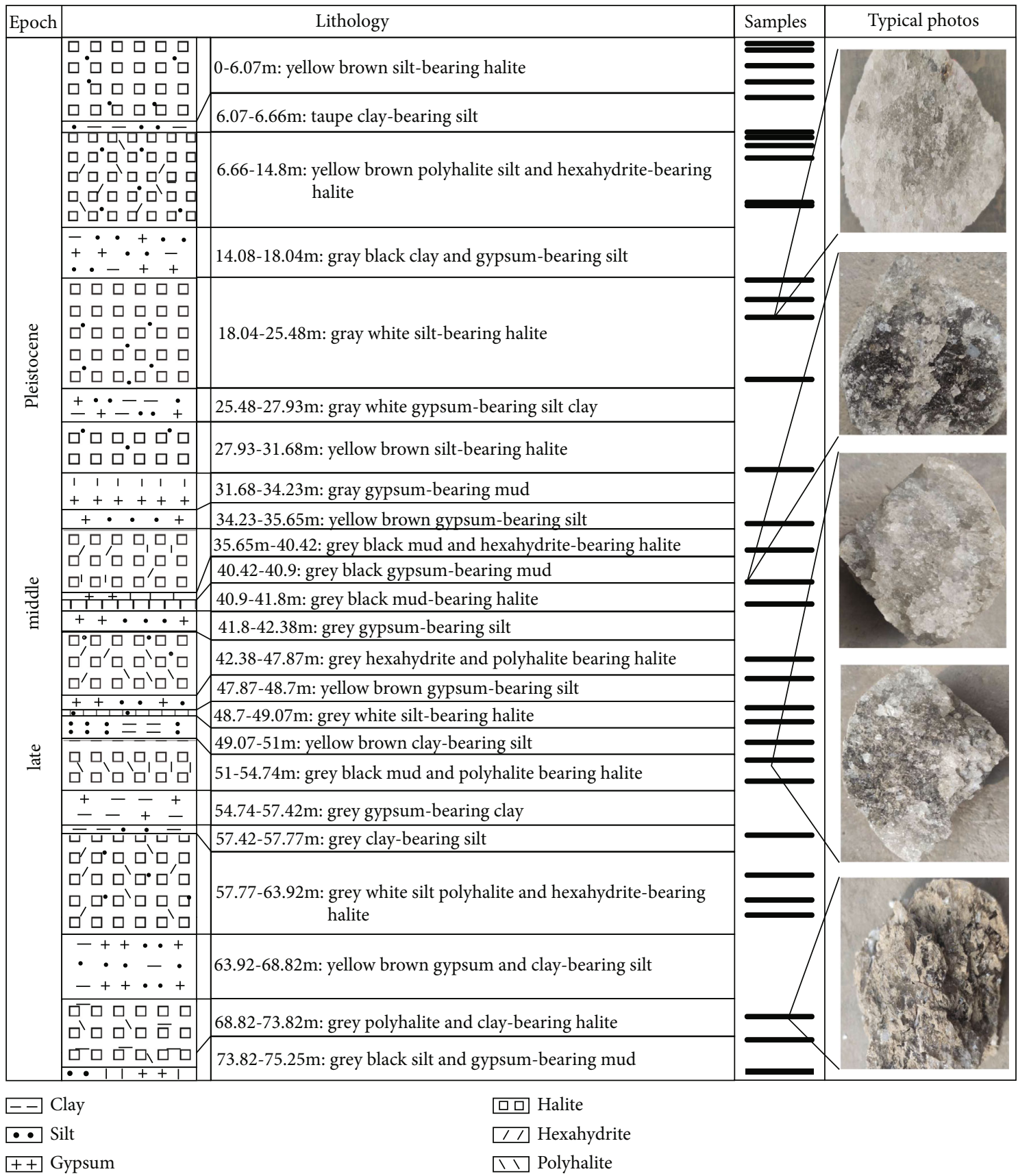

FIGURE 2: ZK3608 lithology description, sampling point location, and typical hand specimen.

dominate these samples (Figure 3). The primary fluid inclusions are mostly distributed along the growth zone of primary halite and also show cumulate and chevron distribution characteristics. The sample analytical methods followed those work [23]. Halite chips were prepared by cleaving 2-3 mm thick fragments with a razor blade. The prepared halite slices containing primary fluid inclusions are stored in a plastic box with a desiccant for temperature measurement. Some inclusions are gas-liquid two-phase because they cannot provide accurate temperature. Only the primary single-phase aqueous liquid inclusions within cloudy fluid inclusion bands in chevron and cumulate crystals were selected in our study for homogenization temperature analysis. Through observation of the whole rock sample of the halite salt layer, typical primary polyhalite is found, which is associated with halite. The boundary between the two minerals is clear, and there is no sign of metasomatism, which is the primary mineral precipitated from brine (Figure 4). It can be seen from hand specimen observation that gray-white polyhalite minerals are associated with halite (Figure 4 ). This provides direct mineralogical evidence for retrieving the ore-formed temperature of polyhalite from the temperature of ancient brine. 


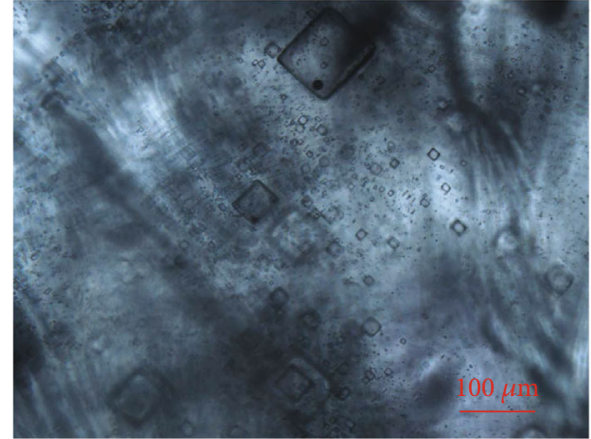

(a)

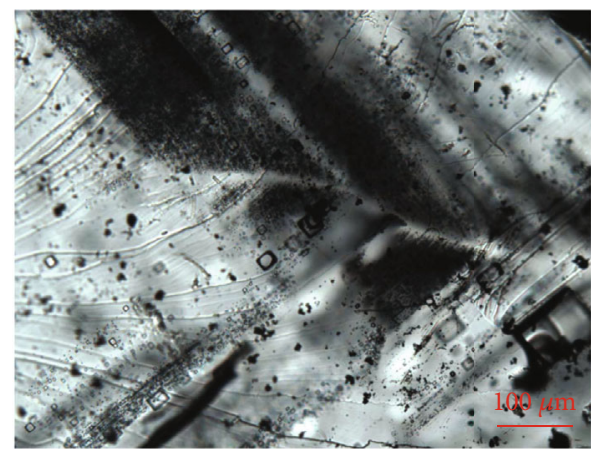

(c)

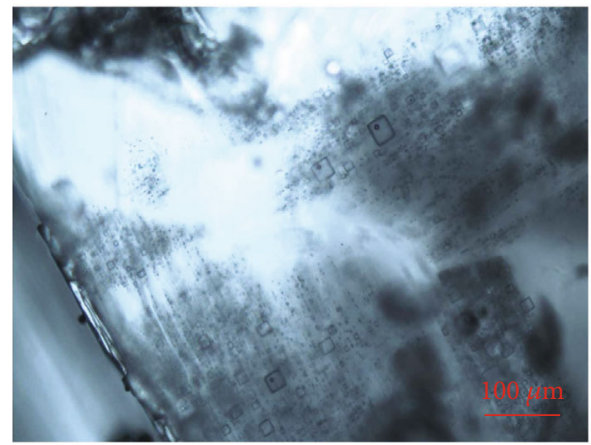

(e)

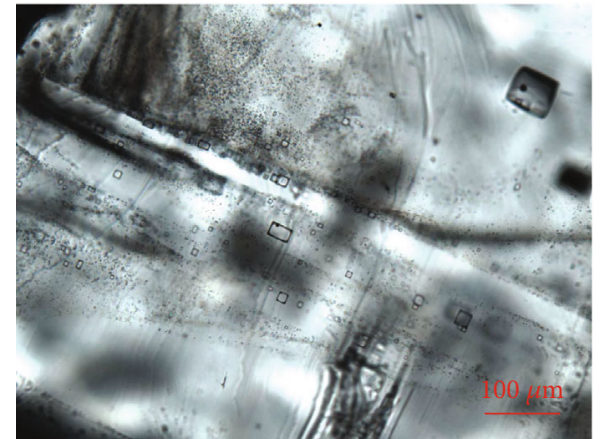

(b)

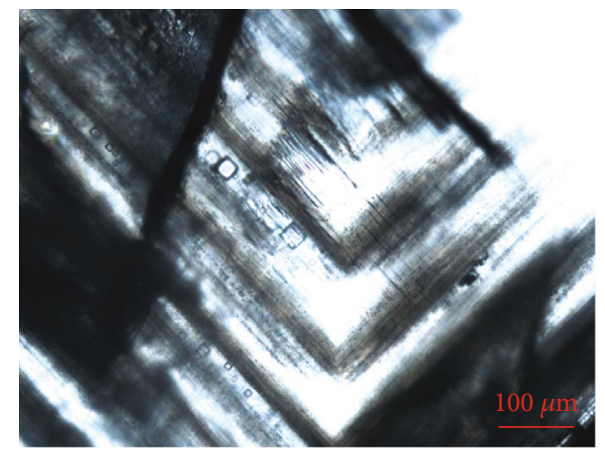

(d)

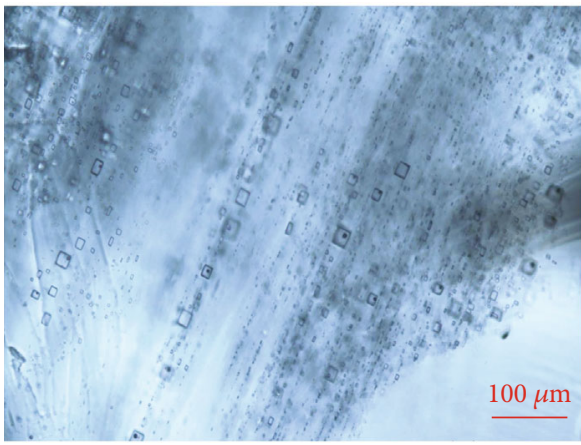

(f)

FIGURE 3: Petrologic characteristics of halite fluid inclusions: $(a, b)$ fluid inclusion banding containing gas-liquid two-phase inclusion; (c, d) chevron fluid inclusion banding distribution structure; $(e, f)$ a large number of gas-liquid two-phase inclusions appear after freezing with liquid nitrogen.

3.2. Method. There are two ways to freeze and nucleate halite fluid inclusions: one is to freeze slowly in the refrigerator for about two weeks and the other is to freeze quickly with liquid nitrogen on the cold and hot stage. Through the experimental study on the $T_{\mathrm{h}}$ of synthetic halite fluid inclusions, it is proven that the rapid freezing of liquid nitrogen can also provide reliable temperature data $[47,48]$. We used liquid nitrogen rapid freezing and refrigerator slow freezing methods to test the $T_{\mathrm{h}}$ of artificially synthesized halite fluid inclusions and found that the maximum $T_{\mathrm{h}}$ data obtained by the two methods are very close to the set constant temperature evaporation temperature [49]. This method is also widely used in the study of $T_{\mathrm{h}}$ of fluid inclusions in salt-bearing strata such as the Jialingiiang Formation in the Sichuan Basin, Shashi Formation in the Jiangling Sag, Mengyejing in Yunnan, and Qarhan Bieletan section and Cordillera de los Andes in South America [50-54]. It shows that it is feasible to use liquid nitrogen to freeze and nucleate directly on the cold and hot stage, and this temperature measurement work is also carried out by using a liquid nitrogen rapid freezing method.

Firstly, the sheet to be measured is placed on a cold and hot stage, connected with liquid nitrogen and cooled to $-18^{\circ} \mathrm{C}$. On the premise of ensuring that the inclusions do not freeze and not damage the size and shape, some single liquid-phase halite inclusions appear to have bubbles due to condensation and contraction, forming gas-liquid two-phase inclusions. Then, after enough gas-liquid two-phase inclusions appear, the temperature rise test is carried out. In order to ensure the data to be as accurate as possible, the temperature rise rate is $0.5^{\circ} \mathrm{C} / \mathrm{min}$ within $15^{\circ} \mathrm{C}$, and the rate drops to $0.1^{\circ} \mathrm{C} / \mathrm{min}$ when the temperature is above $15^{\circ} \mathrm{C}[23,24]$. The temperature at which the vapor bubbles disappeared was recorded. All the sample 


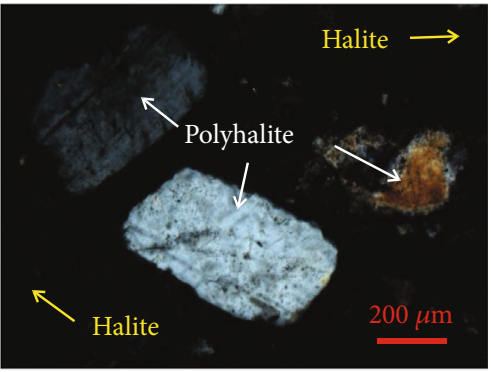

(a)

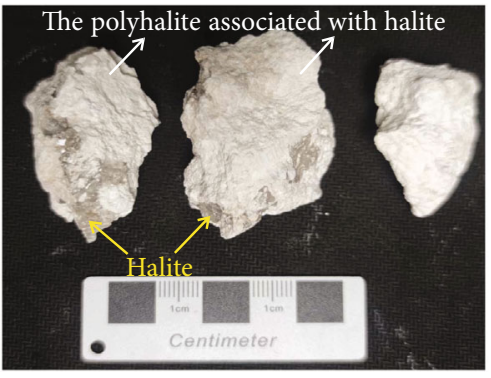

(c)

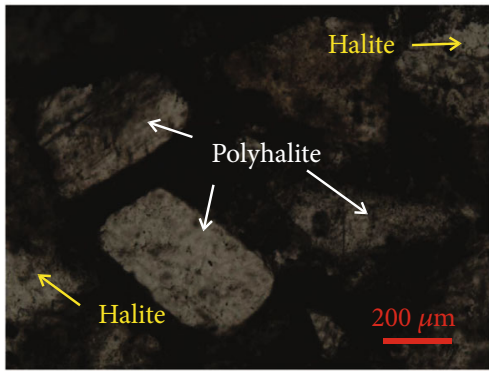

(b)

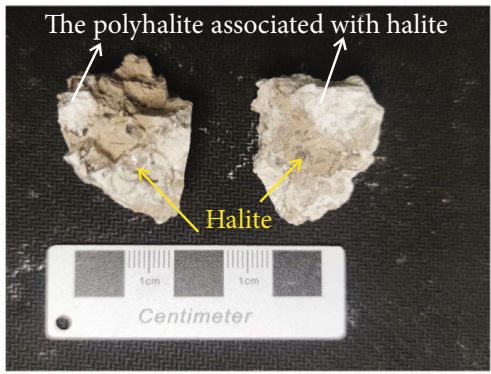

(d)

FIGURE 4: The microscopic morphology of polyhalite in KSL: $(a, b)$ the relationship between polyhalite and halite in the halite layer; (c, d) relationship between polyhalite and halite in the hand specimen (from [55]).

preparation and microthermometric works were made in Minerals Lab, Qinghai Institute of Salt Lakes, Chinese Academy of Sciences.

\section{Results and Discussion}

Although a total of 45 halite samples were obtained, among them, 5 halite samples (nos. 4, 27, 28, 33, and 37) did not develop fluid inclusions and 6 samples (nos. 16, 17, 23, 24, 26 , and 31) did not freeze out bubbles needed for temperature measurement after long-term freezing. So an amount to 472 fluid $T_{\mathrm{h}}$ data was observed and measured from 34 halite samples (Table 1). In 472 temperature data, the minimum is $4.5^{\circ} \mathrm{C}$, the maximum is $35.5^{\circ} \mathrm{C}$, and the average value is $17.0^{\circ} \mathrm{C}$ (Table 1 ). Characteristics of temperature data of 34 halite samples are shown in Table 1 . Since the $T_{\text {hMAX }}$ is often used to study brine temperature, this paper mainly discusses the characteristics of the $T_{\text {hMAX }}$ of 34 halite samples. The $T_{\text {hMAX }}$ of 34 halite samples ranges from 17.1 to $35.5^{\circ} \mathrm{C}$, with an average value of $22.1^{\circ} \mathrm{C}$, among which the temperature of 24 samples is between 17 and $23^{\circ} \mathrm{C}$ (Figure 5). In a word, the overall temperature is low.

4.1. Fluid Inclusion $\mathrm{T}_{h}$ and $\mathrm{K}^{+}, \mathrm{Mg}^{2+}$, and $\mathrm{Ca}^{2+}$ in $\mathrm{KSL}$ Halite. Thirty-four samples with enough $T_{\mathrm{h}}$ data were frozen by liquid nitrogen, so that the bubble appearance time was basically within $1.7 \mathrm{~h}$. However, the freezing time of no. $16,17,23,24,26$, and 31 samples was close to or exceeded $5 \mathrm{~h}$, respectively (Table 2 ); still, no bubbles appear, so give up the $T_{\mathrm{h}}$ test. The scholar pointed out that freezing nucleation is difficult for some halite samples buried deep and deposited with potassium and magnesium salts [56]. Besides the experimental study on the effects of $\mathrm{K}^{+}, \mathrm{Mg}^{2+}$, and $\mathrm{Ca}^{2+}$ content on the $T_{\mathrm{h}}$ of fluid inclusions in halite, it was found that the higher the $\mathrm{Mg}^{2+}$ content, the more difficult it is to freeze and nucleate, and the content of $\mathrm{K}^{+}$has certain influence but is not the main factor [48]. The 40 halite samples obtained from ZK3608 not only tested the homogenization temperature of fluid inclusions but also tested the chemical composition of fluid inclusions [57]. The mean contents of $\mathrm{K}^{+}$and $\mathrm{Mg}^{2+}$ in 40 halite fluid inclusions are $17.1 \mathrm{~g} / \mathrm{l}$ and $41.2 \mathrm{~g} / \mathrm{l}$, respectively, and the median contents of $\mathrm{K}^{+}$and $\mathrm{Mg}^{2+}$ are $12.5 \mathrm{~g} / \mathrm{l}$ and $39.4 \mathrm{~g} / \mathrm{l}$, respectively [57]. The sample information of 6 unfrozen nucleation and adjacent horizons is shown in Table 2, and the composition data of sample 26 without inclusion is also shown. Samples 23, 24, and 26 have high $\mathrm{K}^{+}$and $\mathrm{Mg}^{2+}$ content; in particular, $\mathrm{Mg}^{2+}$ content far exceeds the average and median of $\mathrm{Mg}^{2+}$ in 40 halite fluid inclusions. In addition, it was found that samples 16,17 , and 31 had high $\mathrm{K}^{+}$and $\mathrm{Mg}^{2+}$ contents, especially $\mathrm{Mg}^{2+}$ contents, and samples in adjacent 5horizons $(15,18,30$, and 32$)$ had the same high $\mathrm{K}^{+}$and $\mathrm{Mg}^{2+}$ contents. Even though a few inclusion data were obtained, the freezing time was longer (Table 2). It shows that not only the contents of $\mathrm{K}^{+}$and $\mathrm{Mg}^{2+}$, especially $\mathrm{Mg}^{2+}$, have an influence on freezing nucleation during temperature measurement of fluid inclusions in halite under laboratory conditions, but also the same scientific problems exist under actual natural conditions.

In addition, the experimental study shows that compared with the simple sodium chloride system, the existence of $\mathrm{K}^{+}$, $\mathrm{Mg}^{2+}$, and $\mathrm{Ca}^{2+}$ will cause the $T_{\mathrm{hMAX}}$ of halite fluid inclusions to be higher than the actual brine temperature during crystallization; in particular, $\mathrm{K}^{+}$has a significant impact [48]. The existence of $\mathrm{K}^{+}$and $\mathrm{Mg}^{2+}$, especially $\mathrm{Mg}^{2+}$, has an impact on the temperature measurement process. It is reasonable to believe that the existence of $\mathrm{K}^{+}, \mathrm{Mg}^{2+}$, and $\mathrm{Ca}^{2+}$ under natural 
TABLE 1: Summary of homogenization temperatures of halite fluid inclusions.

\begin{tabular}{|c|c|c|c|c|c|c|c|c|c|c|c|}
\hline Serial no. & $T_{\mathrm{hMIN}}\left({ }^{\circ} \mathrm{C}\right)$ & $T_{\text {hMAX }}\left({ }^{\circ} \mathrm{C}\right)$ & $T_{\text {hAVG }}\left({ }^{\circ} \mathrm{C}\right)$ & Depth (m) & $N$ & Serial no. & $T_{\mathrm{hMIN}}\left({ }^{\circ} \mathrm{C}\right)$ & $T_{\text {hMAX }}\left({ }^{\circ} \mathrm{C}\right)$ & $T_{\mathrm{hAVG}}\left({ }^{\circ} \mathrm{C}\right)$ & Depth $(\mathrm{m})$ & $N$ \\
\hline 01 & 12.7 & 23.0 & 17.2 & 1.0 & 13 & 18 & 10.7 & 19.0 & 14.8 & 37.6 & 16 \\
\hline 02 & 14.0 & 22.0 & 17.4 & 1.5 & 15 & 19 & 9.5 & 25.0 & 17.2 & 39.9 & 24 \\
\hline 03 & 15.2 & 25.6 & 20.2 & 2.6 & 15 & 20 & 9.0 & 22.5 & 16.2 & 41.5 & 8 \\
\hline 04 & 15.6 & 25.4 & 19.1 & 3.8 & 20 & 21 & 15.5 & 31.0 & 22.4 & 45.5 & 8 \\
\hline 05 & 19.8 & 35.5 & 25.8 & 4.9 & 12 & 22 & 10.5 & 19.3 & 15.3 & 46.9 & 19 \\
\hline 06 & 15.5 & 22.0 & 18.2 & 7.4 & 13 & 23 & 4.5 & 22.0 & 9.9 & 49.0 & 18 \\
\hline 07 & 12.0 & 22.0 & 16.3 & 7.8 & 9 & 24 & 12.0 & 22.0 & 16.1 & 50.0 & 14 \\
\hline 08 & 11.6 & 30.0 & 21.8 & 8.4 & 17 & 25 & 13.0 & 19.5 & 15.9 & 51.5 & 16 \\
\hline 09 & 9.3 & 18.6 & 15.8 & 9.3 & 6 & 26 & 10.2 & 19.3 & 14.3 & 52.8 & 12 \\
\hline 10 & 13.0 & 21.0 & 15.8 & 12.5 & 7 & 27 & 13.0 & 25.8 & 21.2 & 54.3 & 6 \\
\hline 11 & 15.1 & 26.1 & 20.6 & 12.7 & 12 & 28 & 16.1 & 28.0 & 23.1 & 58.2 & 14 \\
\hline 12 & 9.9 & 17.5 & 14.3 & 18.1 & 7 & 29 & 12.1 & 18.4 & 14.7 & 61.1 & 13 \\
\hline 13 & 18.0 & 18.0 & 18.0 & 19.5 & 1 & 30 & 9.0 & 18.1 & 13.4 & 62.9 & 18 \\
\hline 14 & 11.0 & 17.9 & 14.8 & 20.8 & 22 & 31 & 9.7 & 17.1 & 12.8 & 64.0 & 10 \\
\hline 15 & 10.0 & 20.5 & 15.9 & 25.3 & 19 & 32 & 13.0 & 21.0 & 16.2 & 71.2 & 13 \\
\hline 16 & 11.5 & 19.6 & 15.8 & 31.8 & 24 & 33 & 13.0 & 19.2 & 15.6 & 73.0 & 19 \\
\hline 17 & 10.5 & 19.0 & 15.4 & 35.7 & 20 & 34 & 11.9 & 20.1 & 15.5 & 75.3 & 12 \\
\hline
\end{tabular}

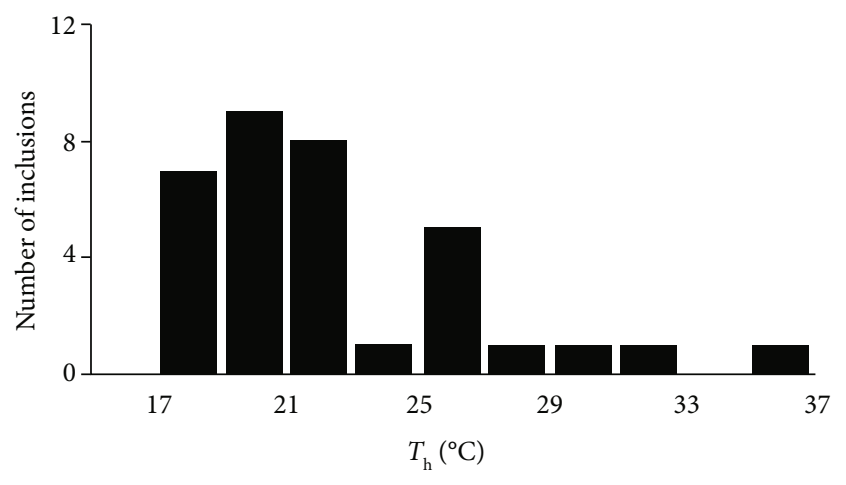

FIGURE 5: The $T_{\text {hMAX }}$ distribution in the Kunteyi halite of borehole ZK3608.

conditions, especially $\mathrm{K}^{+}$, will lead to the higher $T_{\text {hMAx }}$ of halite fluid inclusions. As for whether the existence of $\mathrm{K}^{+}$ and $\mathrm{Mg}^{2+}$ plasma affects the temperature measurement process and leads to high temperature, it needs further study, but it can be proven that the existence of $\mathrm{K}^{+}$and $\mathrm{Mg}^{2+}$ plasma does affect the $T_{\mathrm{h}}$ results under natural conditions. Combined with the chemical composition of ZK3608 halite fluid inclusions [57], the $T_{\mathrm{hMAX}}$ of 34 halites ranging from 17.1 to $35.5^{\circ} \mathrm{C}$ may be higher than the temperature in different historical periods in the study area. Although the specific height cannot be quantified at present, it can be determined that the actual brine temperature and polyhalite ore-formed temperature are a little lower than the tested $T_{\text {hMAX }}$ in the study area since the late Middle Pleistocene.

\subsection{Paleotemperature since the Late Middle Pleistocene of KSL}

4.2.1. Brine Temperature in KSL and QB. In laboratory- and nature-grown halite crystals, the $T_{\mathrm{hMAX}}$ all matched the
TABLE 2: The samples without temperature data and $\mathrm{K}$ and $\mathrm{Mg}$ contents in halite about the same deposition stage.

\begin{tabular}{lccccc}
\hline $\begin{array}{l}\text { Original } \\
\text { no. }\end{array}$ & $\begin{array}{c}\text { Freezing } \\
\text { time }(\mathrm{h})\end{array}$ & Amount & $\begin{array}{c}\text { Depth } \\
(\mathrm{m})\end{array}$ & $\begin{array}{c}\text { AVG } \rho(\mathrm{K}) \\
(\mathrm{g} / \mathrm{l})\end{array}$ & $\begin{array}{c}\text { AVG } \rho(\mathrm{Mg}) \\
(\mathrm{g} / \mathrm{l})\end{array}$ \\
\hline 15 & 5.0 & 8 & 45.5 & 25.4 & 78.0 \\
16 & $>5.0$ & 0 & 44.5 & 17.8 & 82.4 \\
17 & $>5.0$ & 0 & 43.3 & 18.2 & 63.3 \\
18 & 3.0 & 8 & 41.5 & 7.1 & 32.3 \\
23 & $>5.0$ & 0 & 30.5 & 8.0 & 46.6 \\
24 & $>5.0$ & 0 & 29.0 & 16.7 & 77.1 \\
26 & $>5.0$ & 0 & 24.9 & & \\
30 & 3.5 & 1 & 19.5 & 11.7 & 47.9 \\
31 & $>4.3$ & 0 & 19.2 & 12.5 & 48.4 \\
32 & 4.0 & 7 & 18.1 & 15.7 & 47.9 \\
\hline
\end{tabular}

brine temperature $[22,29,58]$. The results showed that the $T_{\text {hMAX }}$ ranges from 17.1 to $35.5^{\circ} \mathrm{C}$ with an average of 22.1 (major concentration $17-23^{\circ} \mathrm{C}$ ) (Figure 5). Since the salt lakes in QB are the common characteristics of Quaternary modern salt lakes in nonmarine environment, our results can be compared with the previous brine temperature data in different geological ages in the basin. Reported temperatures for $\mathrm{QB}$ modern brine evaporites range from 17.9 to $38.2^{\circ} \mathrm{C}$ [26]. Salt lake brine temperatures in the Qarhan Salt Lake (southeast QB) range from 23 to $40^{\circ} \mathrm{C}$ [59]. Brine temperatures of the Chaka Salt Lake (southeast QB) generally range from 19 to $25^{\circ} \mathrm{C}$ but can reach $30^{\circ} \mathrm{C}$ in August [27]. The $T_{\mathrm{h}}$ of halite fluid inclusions in Yiliping Salt Lake reflects the temperature variation range of ancient brine from $21.4^{\circ} \mathrm{C}$ to $30.1^{\circ} \mathrm{C}[60]$. The temperature of ancient brine in the northern area of Bieletan in Qarhan Salt Lake is mainly concentrated at $15-20^{\circ} \mathrm{C}$, and some horizons can reach $28^{\circ} \mathrm{C}$ and 


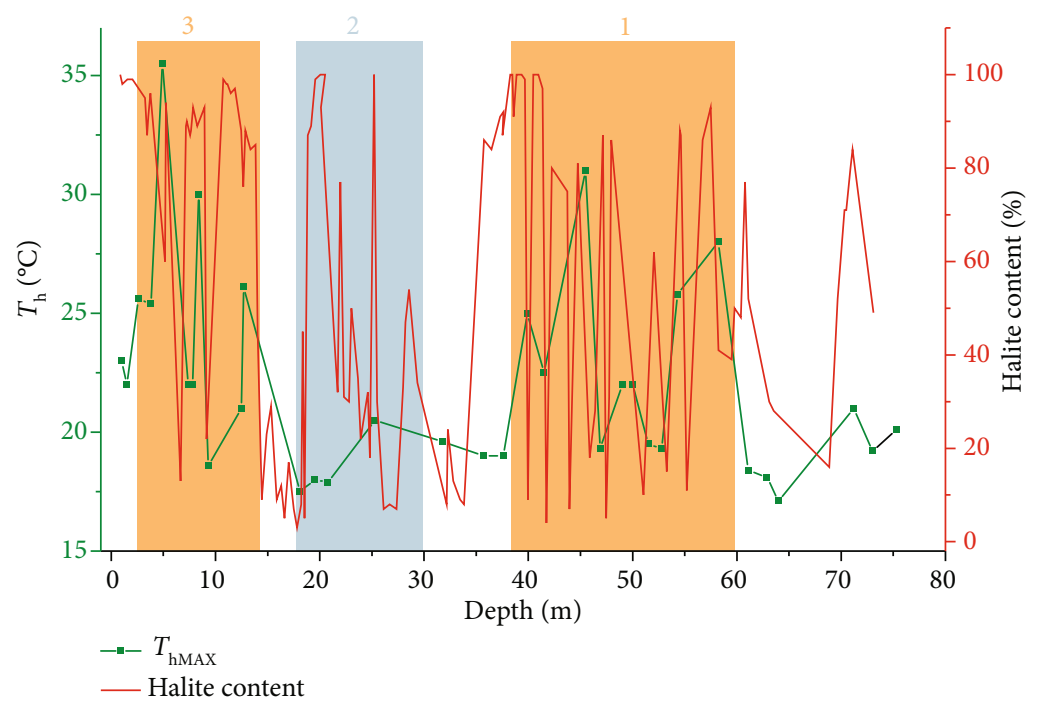

FIGURE 6: Relationship between halite content and ancient brine temperature in the ZK3608 core.

the high-temperature horizons promote the deposition of potassium salt [54]. Core SG-1 was located in Chahansilatu of northwest QB. Based on the study of $\mathrm{Mg}^{2+}$ isotopes of polyhalite and bloedite in core samples, it was suggested that there is existence of a warm dry climate in the $\mathrm{QB}$, with brine temperature as high as $\sim 70^{\circ} \mathrm{C}$ at $0.39 \mathrm{Ma}, 0.36 \mathrm{Ma}$, and $0.12 \mathrm{Ma}$ [61]. According to unpublished age data of ZK3608 $(y=0.249 x-16.611), 0.36 \mathrm{Ma}$ and $0.12 \mathrm{Ma}$ correspond to $73.0 \mathrm{~m}$ and $13.0 \mathrm{~m}$ of ZK3608, respectively, and the latest $T_{\mathrm{h}}$ of halite fluid inclusion results is $19.2^{\circ} \mathrm{C}$ $(72.9 \mathrm{~m})$ and $26.1^{\circ} \mathrm{C}(12.7 \mathrm{~m})$, respectively. It reflects these two periods, and the temperature is relatively high. However, according to isotope results, it is questionable that there is a high temperature of $70^{\circ} \mathrm{C}$.

The temperature are generally consistent with the brine temperature that halite precipitates, which can well reflect the brine temperature. Compared with the brine temperature of other salt lakes in the $\mathrm{QB}$, the range of $17.1-35.5^{\circ} \mathrm{C}$ is reasonable, but the temperature is mainly concentrated at $17-23^{\circ} \mathrm{C}$ (Figure 5), which is generally lower than that of other salt lakes.

4.2.2. Halite Fluid Inclusion $T_{h}$ with Mineral. Halite deposit is the most direct mineral reflecting the sedimentary evolution degree of salt lake, and halite is the mineral that has been running through since the salt formation of KSL. Therefore, through the remarkable sedimentary characteristics of halite, it shows that there are three main salt-forming periods since the Middle Pleistocene in Kunteyi Salt Lake (Figure 6). Combining the relationship between ancient brine temperature and main salt-forming periods, it can be clearly seen that the brine temperature is generally higher in the 1st (59.79-38.26 m) and 3rd (14.05-0 m) salt-forming periods, while the salt content in the 2 nd salt-forming period (29.35-18.37 $\mathrm{m})$ gradually increases, but the brine temperature is always at a lower level (Figure 6). The evaporation rocks in KSL were formed in dry, cold, and slightly acidic oxidation environment [39]. Temperature results show that
KSL not only has salt formation in the cold period but also has salt formation in a relatively warm period, which is dominant. According to the systematic study of salt deposits in the arid salt-forming center areas in China since Quaternary (the salt lake areas in the west of the Qaidam Basin and the east of Tarim Basin), there are several cold-dry salt-forming periods and warm-dry salt-forming periods, while there is a strong cold-wet salt-forming period in $180-140 \mathrm{ka}$ [62]. The salt-forming period of salt lakes in the Qaidam Basin responded to the Quaternary glacial period of QinghaiTibet Plateau to a certain extent, especially in the salt lakes in the western Qaidam Basin, where halite salt layers of the penultimate glacial period (MIS6) were widely developed $[63,64]$, while the second low-temperature salt-forming period $(29.35-18.37 \mathrm{~m})$ divided in this work can be seen from the ZK3608 age frame $(y=0.249 x-16.611)$ whose age span is $185-140.5 \mathrm{ka}$. Obviously, this low-temperature salt-forming period recorded this strong cold and wet event, and it was also a response to the salt-forming period of the penultimate glacial period. To some extent, it shows that the temperature trend of halite fluid inclusions is correct. The ancient brine temperature reflected by halite fluid inclusions shows that the brine and environment temperature in the main salt-forming periods (the first and third saltforming periods) of KSL is higher, which belongs to a relatively warm and dry salt-forming mode, while the short salt-forming period in the second salt-forming stage belongs to cold and wet salt forming. These three salt-forming stages are the main sedimentary periods of polyhalite, among which the first and third relatively warm and dry saltforming periods account for a large proportion. It shows that the ore-formed temperature of polyhalite in KSL is extensive. On the other hand, it shows that in KSL, a relatively dry and hot salt-forming model is dominant, which promotes the extensive production and deposition of polyhalite.

The phase diagrams of epsomite, hexahydrite, and kieserite under certain temperature and humidity conditions [65] are shown in Figure 7. In a certain range of humidity, 


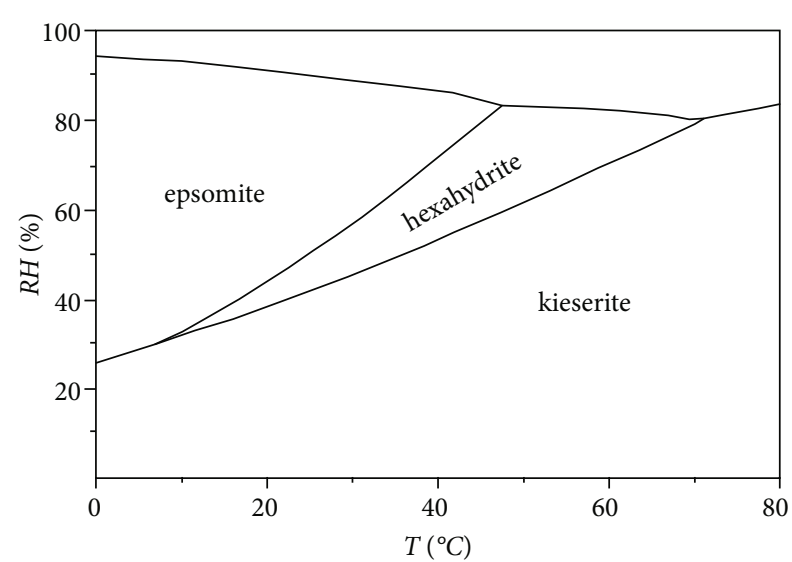

FIgURE 7: Diagram of existence conditions of epsomite, hexahydrite, and kieserite (modified from [65]).

with the increase in temperature, the phase area of salt discharge in hexahydrite increases slowly. According to [57], ZK3608 mineral was analyzed by X-ray powder diffractometry (XRD), and hexahydrite was scattered in the lithology. Comparing the hexahydrite content of ZK3608 with the $T_{\text {hMAX }}$ of halite fluid inclusions (Figure 8), we can see that there is a high similarity between the hexahydrite content and the $T_{\mathrm{hMAX}}$, and the hexahydrite is relatively high in the three main high-temperature stages, but almost no hexahydrite is released in the low-temperature stage. Although the distribution range of hexahydrite release is narrow in the high-temperature stage near the surface, it is a fact that more or less hexahydrite release is precipitated in the hightemperature stage of the core profile, and there is no or only a few hexahydrite release in the low-temperature stage. As far as magnesium sulfate salt is concerned, epsomite tends to be produced at low temperature and high humidity, kieserite tends to be produced at high temperature and moderate humidity, and hexahydrites sandwiched between them are easy to form at moderate temperature and humidity (Figure 8). Combined with the mineral phase diagram of magnesium sulfate double salt, in view of the actual geological background of drought and low temperature in the Kunteyi area, it is unrealistic for epsomite and kieserite to appear in the drill core profile, but it is reasonable for hexahydrite to appear. XRD results of ZK3608 mineral show that only hexahydrite does appear [13]. What is important is that the variation trend of hexahydrite content in the core profile is similar to the $T_{\mathrm{hMAX}}$, which is in accord with the relationship between temperature and hexahydrite revealed by the phase diagram. It shows that the $T_{\mathrm{h}}$ of halite fluid inclusions reflects the actual temperature in the study area to a certain extent.

According to the sediment assemblage and its variation characteristics of KSL, it can be divided into 9 evaporiteclastic sedimentary cycles, and the closer to the surface, the thicker the halite layer $[39,57]$. It shows that the climate change in the study area is generally characterized by oscillation and drying. The $T_{\mathrm{hMAX}}$ of ZK3608 halite fluid inclusions increases gradually from bottom to top and fluctuates on the way, which reflects the variation characteristics of paleoclimate in the study area.

Chlorite generally exists only in glacial areas and in the surface environment with weak chemical weathering, while illite shows that the climate is dry and cold and the leaching effect is weak. The clay mineral combination of chlorite and illite is considered to exist only in glacial areas $[66,67]$. Muscovite is the main illite mineral, and there is a certain amount of chlorite and muscovite deposits in the ZK3608 clastic layer. Although the clay minerals in salt lakes reflect the climate characteristics of the source region more, the content of clay minerals is often low during the dominant period of chemical deposition [68]. Chlorite and muscovite, which should have been deposited in the clastic layer of salt lake, developed in great quantities in the second salt-forming period and deposited with evaporite at the same time, which corresponds to the low $T_{\text {hMAX }}$ stage of halite fluid inclusions (Figure 8). Obviously, the lower temperature of ancient brine and the deposition of a large number of chlorite and muscovite in this period (Figure 8) are the environmental response to the strong cold and humidity during 180$140 \mathrm{ka}$ [62]. The cold glacial climate environment resulted in a large number of chlorite and muscovite in the surrounding alpine provenance, which were transported to salt lake and deposited with evaporite at the same time due to the humid climate conditions. However, in the first relative dry-hot salt-forming period, chlorite and muscovite deposited in the clastic layer between evaporated rock layers and with the $T_{\mathrm{hMAX}}$ of halite fluid inclusions showed a flipped relationship (Figure 8), which confirmed the characteristics of this mineral deposited in the clastic layer. According to the analysis of sedimentary characteristics of minerals, including halite, hexahydrate, muscovite, and chlorite, it is confirmed that the $T_{\text {hMAX }}$ of ZK3608 halite fluid inclusions truly reflects the temperature changes of ancient brine in KSL since the middle Pleistocene.

\subsubsection{Temperature of Ancient Brine Response to Paleoclimate} Variation in the Study Area. The $T_{\mathrm{h}}$ of primary halite fluid inclusions in shallow water can be used to indicate air temperature, indicating that paleotemperature is closely related to brine temperature. As mentioned earlier, the climate of KSL has been mainly dry and cold since the late Pleistocene. Deep borehole (SG-1) was located in Chahansilatu in western QB close to Kunteyi Playa, and research of stable isotopes of carbonates from the SG-1 core suggests that since $0.6 \mathrm{Ma}$, the climate in northwest China has been in a longterm dry and cold state, which is mainly affected by global cooling, especially cooling in the high latitudes of the Northern Hemisphere [69]. A $600 \mathrm{~m}$ deep core (SG-3) of lacustrine-playa deposits was obtained from the western Qaidam Basin, and sporopollen results show that from $0.6 \mathrm{Ma}$ and $0.15 \mathrm{Ma}$ to late Pliocene, Ephedraceaedominated desert prevailed response to long-term global cooling [70]. As far as climate is concerned, both regional short-time scale climate characteristics and global longtime scale climate conditions have proven that the paleoclimate in the study area has been mainly dry and cold since the end of the late Pleistocene. 


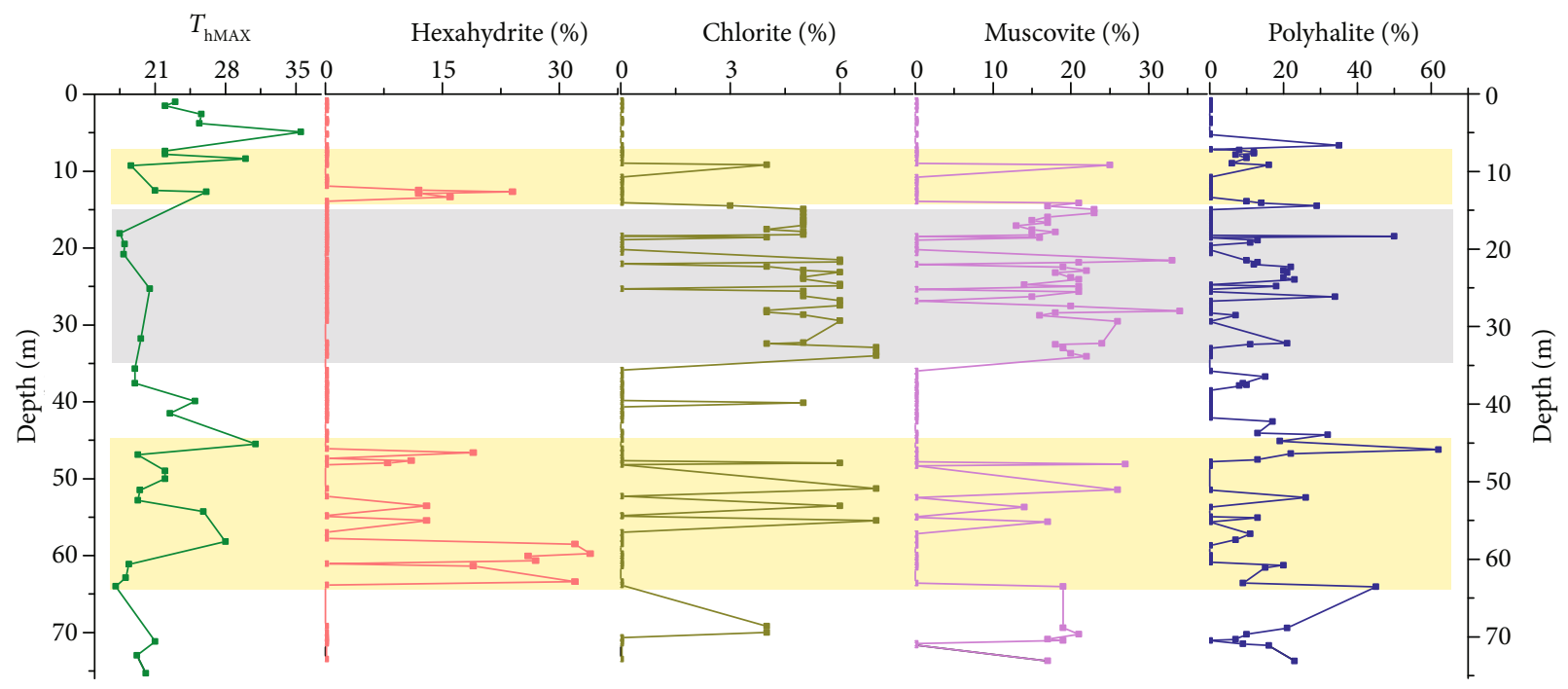

Figure 8: Plots showing concentrations of different minerals along the depth of the borehole and its relationship with $T_{\mathrm{hMAX}}$.

Through the evidence of brine temperature of other salt lakes in QB, mineral sedimentary, and paleoclimate characteristics in the study area, it shows that the temperature range of $17.1-35.5^{\circ} \mathrm{C}$, mainly concentrated at $17-23^{\circ} \mathrm{C}$, faithfully reflects the ancient brine temperature characteristics of KSL since the late Middle Pleistocene.

4.3. Ore-Formed Temperature of Polyhalite in KSL. Salt minerals were divided into three types: cold phase, warm phase, and wide temperature phase, and polyhalite was identified as wide temperature-phase mineral [62]. The widespread existence of polyhalite in ancient and modern evaporite deposits [71], to a certain extent, explains the wide temperature range of polyhalite mineralization in nature. It can be seen from the phase diagram of the five-element system superimposed by calcium ions that the polyhalite phase area is very small when the temperature is less than $32.5^{\circ} \mathrm{C}$, and the polyhalite phase area expands rapidly when the temperature is $55^{\circ} \mathrm{C}$ [72]. Polyhalite crystallisation slows down, when at lower temperatures [73]. Polyhalite can be synthesised under laboratory conditions by a reaction of gypsum with appropriate solutions in the ternary system $\mathrm{K}_{2} \mathrm{SO}_{4}-\mathrm{MgSO}_{4}-\mathrm{H}_{2} \mathrm{O}$ at temperatures above $70^{\circ} \mathrm{C}$ [74]. Through EQL/EVP hydrogeochemistry software, the Kunteyi polyhalite ore-forming fluid was simulated under different temperature conditions, and it was found that low temperature was not conducive to polyhalite mineral deposition, while polyhalite was easy to deposit under high-temperature conditions [75]. In Lop Nur western China, polyhalite has been deposited many times in a short time, which is considered to be mainly affected by climate fluctuations with high temperature [10]. The polyhalite microfabrics in an Alpine evaporite melange of Eastern Alps have a formation temperature of $61.4^{\circ} \mathrm{C}$ in the presence of halite [76]. As mentioned earlier, the salt lake brine temperature was at a high level during the formation of polyhalite in SG-1 drilling at Chahansilatu [61]. Whether it is the indoor experimental study of polyhalite or the explo- ration of the formation temperature of polyhalite in nature, it shows that polyhalite is more inclined to form at higher temperature.

Although paleoclimate research shows that the climate of KSL is relatively dry and cold in this period, through combining the relationship between evaporite and ancient brine temperature, it is found that brine and environment temperature was relatively high when the main evaporite was formed in KSL, while polyhalite was mainly formed in this relatively high-temperature salt formation process. In addition, polyhalite peaks at $46 \mathrm{~m}$, and the temperature of ancient brine is relatively high. It is proven that the enrichment characteristics of polyhalite in KSL at relatively high temperature in this low-temperature environment are consistent with the conclusion that polyhalite is easier to develop at high temperature. At the same time, the polyhalite developed in the first and third relatively dry and hot salt-forming environments, while the polyhalite also developed in the second strongly cold and humid salt-forming environment (Figure 8), which indicated that the polyhalite in KSL has strong adaptability to temperature and is a mineral with a wide temperature phase. It also proves to some extent that temperature has a limited effect on the formation of polyhalite. Numerous evidences show that polyhalite tends to be deposited at high temperature, and the low temperature of brine in KSL during this period may be one of the reasons why polyhalite did not develop on a larger scale.

\section{Summary and Conclusion}

(1) Polyhalite is mostly formed in the relatively hightemperature stage in the low-temperature environment, and the relatively high-temperature conditions promote the formation of polyhalite in KSL

(2) Polyhalite has a strong adaptability to temperature and is a mineral with a wide temperature phase; while temperature has limited influence on 
polyhalite formation, it is deposited at different temperatures

(3) In the evaporite geological environment, in sedimentary areas with high $\mathrm{K}^{+}$and $\mathrm{Mg}^{2+}$ content, especially in areas with high $\mathrm{Mg}^{2+}$ content, $\mathrm{Mg}^{2+}$ has an important influence on the freezing process of the cooling nucleation method of halite fluid inclusions. We according to the previous experimental research speculate that the actual ore-formed temperature of polyhalite in KSL is lower than the measured $T_{\mathrm{h}}$

\section{Data Availability}

The data used to support the findings of this study are available from the corresponding authors upon request.

\section{Conflicts of Interest}

The authors declare that they have no conflicts of interest.

\section{Acknowledgments}

This research was supported by the National Key Research and Development Program of China (Grant No. 2018YFC0406605), National Natural Science Foundation of China (Grant Nos. 41672087 and 41402082), Foundation of Qinghai Science \& Technology Department (2014-ZJ704, 2019-ZJ-7004), and West Light Foundation of Chinese Academy of Sciences (Grant to YS Du).

\section{References}

[1] K. Pavuluri, Z. Malley, and M. K. Mzimbiri, "Evaluation of polyhalite in comparison to muriate of potash for corn grain yield in the Southem Highlands of Tanzaria," International Scholars Journals, vol. 5, no. 3, pp. 325-332, 2017.

[2] A. K. Sutradhar, D. E. Kaiser, and C. J. Rosen, "Evaluation of polyhalite as a source of potassium and sulfur for acornsoybean rotation in Minnesota," Proceedings of the 46th North Central Extension-Industry Soil Fertility Conference, vol. 32, pp. 125-135, 2016.

[3] F. H. Stewart, "The mineralogy of the British Permian evaporites," Mineralogical magazine and journal of the Mineralogical Society, vol. 34, pp. 460-470, 1965.

[4] D. G. Harville and S. J. Fritz, "Modes of diagenesis responsible for observed succession of potash evaporites in the Salado Formation, Delaware Basin, New Mexico," Journal of Sedimentary Petrology, vol. Vol. 56, no. 5, pp. 648-656, 1986.

[5] H. Rahimpour-Bonab, Z. Shariatinia, and M. G. Siemann, "Origin and geochemistry of Miocene marine evaporites associated with red beds: Great Kavir Basin, Central Iran," Geological Journal, vol. 42, no. 1, pp. 37-54, 2007.

[6] X. Z. Huang, "The first polyhalite deposit of China," Yunnan Geology, vol. 15, no. 1, pp. 52-61, 1996.

[7] Y. T. Lin and J. Q. He, "The characters and genies meanings of shallow polyhalite potash deposit in Huayingshan, Sichuan," Geology of Chemical Minerals, vol. 26, no. 3, pp. 145-149, 2004.

[8] Y. J. Zhao, C. L. Liu, T. Ding et al., "Origin and depositional paleoenvironment of Triassic polyhalite in the Jialingjiang
Formation, Sichuan Basin," Carbonates and Evaporites, vol. 35, no. 2, pp. 1-17, 2020.

[9] M. L. Wang, "The geological significance of polyhalite in depression Q," Geological Review, vol. 28, no. 1, pp. 29-37, 1982.

[10] C. L. Liu, M. L. Wang, P. C. Jiao et al., "Sedimentary characteristics and origin of polyhalite in Lop Nur salt lake, Xinjiang," Mineral Deposits, vol. 27, no. 6, pp. 705-713, 2008.

[11] D. J. Zhao, W. T. Han, K. Q. Cai, and J. H. Gao, "The study of polyhalite genesis and its significance of potash-finding in Dawenkou depression, Shandong Province," Earth ScienceJournal of Wuhan College of Geology, vol. 12, no. 4, pp. 342356, 1987.

[12] Z. Liu, D. L. Gao, X. L. Yuan, Y. Zhang, and B. L. Li, “Sedimentary characteristics and origin of polyhalite of Kunty salt lake mine in Qaidam Basin," Journal of Salt Lake Research, vol. 23, no. 1, pp. 30-37, 2015.

[13] X. Zhang, X. Y. Zhang, W. L. Miao et al., "Genesis of polyhalite in Kunteyi Salt Lake based on mineralogical analysis-taking ZK3608 borehole in Dayantan mining area as an example," Journal of Salt Lake Research, vol. 1, no. 28, pp. 45-51, 2020.

[14] Z. Y. Ai, Y. S. Li, Q. L. Tang et al., "Preliminary study on the source of formation-ore fluids of polyhalite in Kunty Playa based on hydrogeochemical simulation," Journal of Salt Lake Research, vol. 26, no. 4, pp. 44-50, 2018.

[15] H. W. Xu, X. F. Guo, and J. M. Bai, “Thermal behavior of polyhalite: a high-temperature synchrotron XRD study," Physics and Chemistry of Minerals, vol. 44, no. 2, pp. 125-135, 2017.

[16] H. D. Cheng, J. Li, Q. Y. Hai, J. G. Song, and X. H. Ma, "Raman and XRD study of polyhalite ore during calcinations," Vibrational Spectroscopy, vol. 102, pp. 63-70, 2019.

[17] L. P. Ogorodova, M. F. Vigasina, L. V. Mel'chakova, I. A. Bryzgalov, and D. A. Ksenofontov, "Enthalpy of formation of natural polyhalite," Geochemistry International, vol. 54, no. 7, pp. 645-649, 2016.

[18] L. Soliev, "Phase equilibria in the $\mathrm{Na}, \mathrm{K}, \mathrm{Mg}, \mathrm{Ca} \| \mathrm{SO}_{4}, \mathrm{Cl}-\mathrm{H}_{2} \mathrm{O}$ system at $50^{\circ} \mathrm{C}$ in the polyhalite crystallization region," Russian Journal of Inorganic Chemistry, vol. 61, no. 4, pp. 511-517, 2016.

[19] X. F. Guo and H. W. Xu, "Enthalpies of formation of polyhalite: a mineral relevant to salt repository," The Journal of Chemical Thermodynamics, vol. 114, pp. 44-47, 2017.

[20] S. M. Roberts and R. J. Spencer, "Paleotemperatures preserved in fluid inclusions in halite," Geochimica et Cosmochimica Acta, vol. 59, no. 19, pp. 3929-3942, 1995.

[21] E. Roedder, "The fluids in salt," American Mineralogist, vol. 69, pp. 413-439, 1984.

[22] T. K. Lowenstein, J. R. Li, and C. B. Brown, "Paleotemperatures from fluid inclusions in halite: method verification and a 100,000 year paleotemperature record, Death Valley, CA," Chemical Geology, vol. 150, no. 3-4, pp. 223-245, 1998.

[23] K. C. Benison and R. H. Goldstein, "Permian paleoclimate data from fluid inclusions in halite," Chemical Geology, vol. 154, no. 1-4, pp. 113-132, 1999.

[24] F. W. Meng, P. Ni, J. D. Schiffbauer et al., "Ediacaran seawater temperature: evidence from inclusions of Sinian halite," Precambrian Research, vol. 184, no. 1-4, pp. 63-69, 2011.

[25] J. J. Zambito and K. C. Benison, "Extremely high temperatures and paleoclimate trends recorded in Permian ephemeral lake halite," Geology, vol. 41, no. 5, pp. 587-590, 2013. 
[26] Y. J. Zhao, C. L. Liu, H. Zhang, Z. Q. Li, T. Ding, and M. Q. Wang, "The controls of paleotemperature on potassium salt precipitation in ancient salt lakes," Acta Petrologica Sinica, vol. 31, no. 9, pp. 2751-2756, 2015.

[27] X. Q. Liu, P. Ni, H. L. Dong, and T. G. Wang, "Homogenization temperature and its significance for primary fluid inclusion in halite formed in Chaka salt lake, Qaidam basin," Acta Petrologica Sinica, vol. 23, no. 1, pp. 0113-0116, 2007.

[28] Y. J. Zhao, H. Zhang, C. L. Liu, B. K. Liu, L. C. Ma, and L. C. Wang, "Late Eocene to early Oligocene quantitative paleotemperature record: evidence from continental halite fluid inclusions," Scientific Reports, vol. 4, pp. 1-6, 2014.

[29] X. Y. Zhang, F. W. Meng, W. X. Li, Q. L. Tang, and P. Ni, "Reconstruction of Late Cretaceous coastal paleotemperature from halite deposits of the Late Cretaceous Nongbok Formation (Khorat Plateau, Laos)," Palaeoworld, vol. 25, no. 3, pp. 425-430, 2016.

[30] X. H. Sun, Y. J. Zhao, C. L. Liu, P. C. Jiao, H. Zhang, and C. H. $\mathrm{Wu}$, "Paleoclimatic information recorded in fluid inclusions in halites from Lop Nur, Western China," Scientific Reports, vol. 7, no. 1, pp. 1-10, 2017.

[31] Y. Xu, C. L. Liu, Y. T. Cao, and H. Zhang, "Quantitative temperature recovery from middle Eocene halite fluid inclusions in the easternmost Tethys realm," International Journal of Earth Sciences, vol. 108, no. 1, pp. 173-182, 2019.

[32] M. H. Li, S. R. Sun, M. D. Yan et al., "Late Cretaceous paleoclimate reconstruction from halite in an evaporite deposit on the Khorat Plateau, Laos," Cretaceous Research, vol. 116, article 104589, 2020.

[33] P. X. Zhang, Salt Lake in Qaidam Basin, Science Press, Beijing, 1987.

[34] X. J. Wei and J. X. Jiang, "The evolution of the quaternary salt lake in the Qaidam Basin," Acta Geologica Sinica, vol. 67, no. 3, pp. 255-265, 1993.

[35] M. L. Wang, Z. C. Yang, C. L. Liu, Z. C. Xie, P. C. Jiao, and C. H. Li, Salt Lake Potassium Deposit in Northern Qaidam Basin and Its Development Prospect, Geology Press, Beijing, 1997.

[36] Z. L. Fan, J. N. Chen, Q. W. Dong, X. X. Liu, X. Yue, and X. D. Qiu, "An analysis of geological characteristics of Okubotan potassium deposit in Kunteyi potassium mine in Qinghai Province," China's Manganese Industry, vol. 36, no. 3, pp. 812, 2018.

[37] J. H. Zhang, J. R. Ren, and Z. G. Zhang, "Aquifers hydrogeological characteristics of Kunty salt lake," Journal of Salt Lake Research, vol. 19, no. 2, pp. 7-10, 2011.

[38] Z. S. Sheng, G. Cheng, and C. S. Le, Division and Sedimentary Environment of Quaternary Salt-Bearing Strata in Qaidam Basin, Geological Publishing Press, Beijing, 1991.

[39] F. Q. Han, Q. Huang, K. J. Wang, H. A. Wang, and L. Yuan, "Study of geochemical evolution and palaeoclimatic fluctuation of Kunteyi Salt Lake in the Qaidam Basin, Qinghai," Oceanologia et Limnologia Sinica, vol. 26, no. 5, pp. 502-508, 1995.

[40] S. J. Bao, Detailed Investigation Report of Dayantan Potassium Deposit in Kunteyi Ore Field, Lenghu Town, Bureau of Geological Exploration and Development of Qinghai Province, Xining, Qinghai Province, 2002.

[41] Z. Q. Sheng, G. B. Tong, J. P. Zhang, S. F. Yu, and Y. L. Li, "Geological environments since Pliocene and accumulation process of saline deposit in west Chaidamu Basin, Qinghai,
China," Marine Geology and Quaternary Geology, vol. 10, no. 4, pp. 89-99, 1990.

[42] W. G. Liu, Y. K. Xiao, F. Q. Han, and Z. C. Peng, "Characteristics of chlorine isotopes in salt lakes of Kunteyi and their significance of plaeoclimate," Oceanologia et Limnologia Sinica, vol. 29, no. 4, pp. 431-435, 1998.

[43] Z. Yuan, The Characteristics of Climate since Lake Pleistocene in Lenghu Area of Qaidam Basin and Its Response to Global Climate Change and Uplift of the Plateau, China University of Geosciences, Hubei Province, 2015.

[44] L. A. Hardie, T. K. Lowenstein, and R. J. Spencer, "The problem of distinguishing between primary and secondary features in evaporites," Sixth International Symposium on Salt, vol. 1, pp. 11-39, 1983.

[45] T. K. Lowenstein and L. A. Hardie, "Criteria for the recognition of salt-pan evaporites," Sedimentology, vol. 32, no. 5, pp. 627-644, 1985.

[46] B. Z. Zhang, H. B. Fan, P. X. Zhang, T. K. Lowenstein, and R. J. Spencer, "Hydrogen and oxygen stable isotope analyses of fluid inclusions in halite in Qarhan salt lake with geochemical implications," Acta Sedimentologica Sinica, vol. 8, no. 1, pp. 317, 1990.

[47] X. Chen, Characteristics of Salt-Bearing Series in Eastern Sichuan Basin and Research on Homogenization Temperature of the Fluid Inclusions in Salt, Beijing, Chinese Academy of Geological Sciences, 2014.

[48] J. Li, H. D. Cheng, X. Y. Zhang et al., "Experimental studies of homogenization temperature of fluid inclusions of halite by isothermal evaporation at $25^{\circ} \mathrm{C}$ involving $\mathrm{NaCl}-\mathrm{X}-\mathrm{H}_{2} \mathrm{O}$ $\left(\mathrm{X}=\mathrm{KCl}, \mathrm{MgCl}_{2}, \mathrm{CaCl}_{2}, \mathrm{Na}_{2} \mathrm{SO}_{4}\right.$ ) system," Mineral Deposits, vol. 38, no. 1, pp. 1-9, 2019.

[49] M. WANG, Y. ZHAO, W. LI, and C. LIU, "Fluid inclusions in surface-temperature halite: sample preparation and application," Acta Geologica Sinica, vol. 92, no. 4, pp. 1592-1597, 2018.

[50] C. L. Wang, C. L. Liu, H. M. Xu, L. C. Wang, and L. B. Zhang, "Homogenization temperature study of salt inclusions from the upper section of Shashi Formation in Jiangling depression," Acta Petrologica et Mineralogica, vol. 32, no. 3, pp. 383-392, 2013.

[51] J. Dong, X. Gao, Q. F. Fang, Q. Peng, H. W. Ma, and G. Y. Liu, "The characteristics of halite inclusions in the Mengyejing potash deposit, Yunnan Province, and their palaeoenvironmental significance," Acta Petrologica et Mineralogica, vol. 34, no. 2, pp. 227-236, 2015.

[52] M. Q. Wang, Y. J. Zhao, C. L. Liu, and T. Ding, "Paleotemperature and significance of the evaporated seawater in salt-forming process of the forth member of Jialingjiang Formation in the eastern Sichuan Basin," Acta Petrologica Sinica, vol. 31, no. 9, pp. 2745-2750, 2015.

[53] F. J. Karmanocky and K. C. Benison, "A fluid inclusion record of magmatic/hydrothermal pulses in acid Salar Ignorado gypsum, northern Chile," Geofluids, vol. 16, no. 3, 506 pages, 2016.

[54] D. Wang, Characteristics of Potash Sediment and Paleo Water Temperature in Bieletan Qarhan Salt Lake Qinghai Province, China University of Geosciences, Beijing, 2020.

[55] J. L. X. Y. Zhang, X. Zhang, M. Y. Hu et al., "High-resolution mineralogical investigations on polyhalite-bearing strata in the Kunteyi Salt Lake, Qaidam Basin," Acta Geologica Sinica, vol. 95, no. 7, pp. 2138-2149, 2021. 
[56] Y. J. Zhao, C. L. Liu, H. Zhang, and L. C. Wang, "Analytical method and paleoenvironmental interpretation of fluid inclusion homogenization temperature of ancient halite," Acta Geoscientica Sinica, vol. 34, no. 5, pp. 603-609, 2013.

[57] X. Zhang, Study on Geochemical Characteristics of Paleobrine in Kunteyi Playa Based on Fluid Inclusions Hosted in Halite, University of Chinese Academy of Sciences, Beijing, 2019.

[58] F. W. Meng, P. Ni, C. D. Ge et al., "Homogenization temperature of fluid inclusions in laboratory grown halite and its implication for paleotemperature reconstruction," Acta Petrologica Sinica, vol. 27, no. 5, pp. 1543-1547, 2011.

[59] E. Casas, T. K. Lowenstein, R. J. Spencer, and P. X. Zhang, "Carnallite mineralization in the nonmarine, Qaidam Basin, China: evidence for the early diagenetic origin of potash evaporites," Journal of Sedimentary Petrology, vol. 62, pp. 881-898, 1992.

[60] M. Q. Wang, Origin of Lithium-Rich Brine in Yiliping Salt Lake, Beijing, China University of Geosciences, Qaidam Basin, 2020.

[61] M. H. Li, X. M. Fang, A. Galy, H. L. Wang, X. S. Song, and X. X. Wang, "Hydrated sulfate minerals (bloedite and polyhalite): formation and paleoenvironmental implications," Carbonates and Evaporites, vol. 35, no. 4, pp. 1-12, 2020.

[62] M. P. Zheng, Y. Y. Zhao, and Y. J. Liu, "Quaternary saline Lake deposition and paleoclimate," Quaternary Sciences, vol. 4, pp. 297-307, 1998.

[63] A. D. Chen and M. P. Zheng, "Salt-forming periods in the Qaidam Basin and their correlation with Quaternary glaciations and tectonic movements on the Tibetan plateau," Science \& Technology Review, vol. 35, no. 6, pp. 36-41, 2017.

[64] A. Chen, M. Zheng, G. Song et al., "Evaporite deposits in the Qaidam Basin and their response to Quaternary glacial climates since marine oxygen isotope stage 6 (MIS6)," Geological Review, vol. 66, no. 3, pp. 611-624, 2020.

[65] M. Steiger, K. Linnow, H. Juling et al., "Hydration of MgSO $4 \cdot \mathrm{H}_{2} \mathrm{O}$ and generation of stress in porous materials," Crystal Growth and Design, vol. 8, no. 1, pp. 336-343, 2008.

[66] D. S. Zhao, P. He, H. X. Sun, H. P. Zheng, and Z. F. Lei, "Characteristics and evolution of the clay minerals in Qaidam Basin," Acta Sedimentologica Sinica, vol. 9, no. 1, pp. 66-70, 2001.

[67] Y. J. Tang, J. Y. Jia, and X. D. Xie, "Environment significance of clay minerals," Earth Science Frontiers, vol. 9, no. 2, pp. 337$344,2002$.

[68] X. Y. Zhang, H. Z. Ma, F. Q. Han, Z. Chen, G. C. Cao, and J. G. Wang, "Mineral assemblages and palaeoenvironmental changes of core DG03 of Gahai Lake in Delingha Basin," Acta Sedimentologica Sinica, vol. 25, no. 5, pp. 767-773, 2007.

[69] W. X. Han, X. M. Fang, C. C. Ye, X. H. Teng, and T. Zhang, "Tibet forcing Quaternary stepwise enhancement of westerly jet and central Asian aridification: carbonate isotope records from deep drilling in the Qaidam salt playa, NE Tibet," Global and Planetary Change, vol. 116, pp. 68-75, 2014.

[70] M. T. Cai, X. M. Fang, F. L. Wu, Y. F. Miao, and E. Appel, "Pliocene-Pleistocene stepwise drying of Central Asia: evidence from paleomagnetism and sporopollen record of the deep borehole SG-3 in the western Qaidam Basin, NE Tibetan Plateau," Global and Planetary Change, vol. 94-95, pp. 72-81, 2012.
[71] J. K. Warren, Evaporites: Sediments, Resoureces and Hydrocarbons, Springer Science and Business Media Press, Berlin, Germany, 2006.

[72] F. M. He, S. C. Liu, and C. Q. Bai, Identification Method Manual of Saline Minerals, Chemical Industry Press, Beijing, 1988.

[73] G. Wollmann, Crystallization Fields of Polyhalite and Its Heavy Metal Analogues, University Bergakademie Freiberg, Free State of Saxony, 2010.

[74] D. Freyer and W. Voigt, "Crystallization and phase stability of $\mathrm{CaSO}_{4}$ and $\mathrm{CaSO}_{4}$-based salts," Monatshefte für Chemie, vol. 134, no. 5, pp. 693-719, 2003.

[75] Z. Y. Ai, Study on Formation Mechanism of Polyhalite in Kunteyi Playa Based on Hydrochemical Simulations, University of Chinese Academy of Sciences, Beijing, 2018.

[76] A. Schorn, F. Neubauer, and M. Bernroider, "Polyhalite microfabrics in an Alpine evaporite melange: Hallstatt, Eastern Alps," Journal of Structural Geology, vol. 46, pp. 57-75, 2013. 